\title{
Kalwedo Culture in the Traditional Marriage of the Southwest Moluccas Community
}

\author{
Rifai; Nunuk Suryani; Akhmad Arif Musadad \\ Universitas Sebelas Maret, Indonesia
}

http://dx.doi.org/10.18415/ijmmu.v6i1.622

\begin{abstract}
This article examines the noble values of kalwedo culture that are integrated in the traditional marriage rituals of the West Babar community. The purpose of this study is to study the ritual stages in customary marriage in Southwest Moluccas as well as the meaning and local culture in it. This study uses qualitative methods with data retrieval techniques in the form of observation, interviews and literature studies. The results of the study show that: There are three phases of customary marriage rituals in West Babar, namely the ratutri rania (engagement), rlarawaka tutawula (specialization), and the marriage phase. In its application integrated kalwedo cultural values such as religion, cooperation, mutual cooperation, mutual respect, and social care. These values need to be preserved as part of the local wisdom of the community.
\end{abstract}

Keywords: Kalwedo Culture; Traditional Marriage; West Babar; Southwest Moluccas

\section{Introduction}

Kalwedo is one of culture of existing local in Southwest Moluccas, Moluccas Province, Indonesia. In this culture contained values brotherhood, peace, mutual cooperation, appreciate each other, responsibility, and social care. Those values are can be found in ritual of customary done the local community, one of them is customary ritual marriage. In general indigenous peoples in West Babar (Southwest Moluccas) still revere norms customary particularly in the mating ritual. Kalwedo as the basis the guidelines on the community internalitation in every phase of mating customs. This is done to keep value defend sublime who inherited by their ancestors. Even local community believe that the mating ritual that is not in accordance with the rules of the customs will end up with a breakup is disappointing (divorce).

In the past, the people of Southwest Moluccas recognized the marriage tradition through matchmaking. Even though it was arranged but most couples can live shamans and happy. Local people believe that this can all happen because of the existence of well-practiced rite norms. In addition, in this match, it also implies the existence of respect for parents' children. Choose those who are betrothed as their parents' choice. Along with every passing day, then in the modern era when this of course have to be waning related to ownership an arranged marriage. The moment of the young girl and young boy who getting married more given the freedom to determine a couple of his life. But in fact, that freedom does 
not guarantee the unity and happiness of the couple. Life Indigenous people believe that it happened because of disobedience of norms custom.

Customary marriage is very important for the people of West Babar. Marriage must be carried out in accordance with the traditional norms of Kalwedo which have been determined by the ancestors. Marriage that does not heed the traditional rules of kalwedo is believed not to be lasting and happy. The practice of customary marriage by the West Babar community in general tends to only carry out mating (formal marriage), because it is seen as a respectable marriage. As for the type of elopement, it tends not to be practiced because it is considered to embarrass the family. If there are certain cases such as elopement, it will be subject to severe sanctions based on the provisions of nyotalewta which are manifestations of the kalwedo culture itself. Likewise, the violations called aklira (adultery) are also subject to severe sanctions. In traditional marriage rituals, it is also known as the mating property. Mating assets are one of the most important elements in a marriage. The marriage assets given by the male to the female family are generally in the form of gold, basta cloth, sheep and pigs. Basta fabric is a custom fabric whose width, type and function are arranged in nyotalewta. This basta cloth has motifs and patterns similar to Indian fabrics. High-value basta cloth is called iriratailewruri, in which there is a picture of a king and an arrow. By custom, this type of basta cloth has a higher value than red basta (wutmermera). Similar to indigenous peoples in other regions such as Sulawesi, marriage assets are still an important element in marital customs in West Babar. Nevertheless, for them the property is symbolic, because it must be returned to the male family. Marriage assets are not an absolute requirement in customary marriage. For the people of West Babar the most valuable assets to be brought into marriage life are kalwedo (safety, peace) and niolilieta (family, mutual respect).

It is interesting that the kalwedo culture as a cultural heritage of the ancestors of the Southwest Moluccas islands is so dominant in the traditional marriage rituals in West Babar. The elements of kalwedo are fused at each stage of the traditional marriage ritual. In this article, these stages will be discussed along with the meanings in them.

\section{Research Methods}

This study uses qualitative methods with data retrieval techniques in the form of observation, interviews and literature studies. The literature study was carried out by analyzing books, journals and articles related to Kalwedo culture and traditional marriage traditions in Southwest Moluccas. This research was conducted to understand the cultural values of Kalwedo in traditional marriage rituals in Southwest Maluku.

\section{Result and Discussion}

Customary official marriage is a marriage that is deemed honorable because it is carried out in accordance with the traditional norms of Kalwedo. In fact, it appears that official betrothal marriage is one of the values of a very sacred and lively ritual. Formal marriages are usually preceded by two important phases, namely the engagement phase and the phase of engagement (Leunupun, 2012). According to Verkuyl (1979: 48), the engagement phase is the test phase as the preparation period before entering the marriage phase. The special phase is a series of ritual actions, in which the male and female parties are found, know each other, to enter the marriage phase. 


\section{Engagement Phase}

Engagement phase or ratutri rani is the preparation phase before entering the marriage phase. In this phase, one bond has been established between the prospective bridegroom and the prospective female bride called the engagement bond. In the past, this engagement bond was only known by the parents of the two brides. Its nature is very closed because it still applies the determination of a mate by parents.

The arrival of prospective bridegrooms to meet the bride's family always uses the kalwedo greetings. The greeting is a greeting in building good relations with the female family. This shows that the traditional norms of kalwedo have always been a measure in determining the life partner who wants to be engaged. The values that are expected to emerge at this stage are the value of peace, courtesy, responsibility, honesty, loyalty, attitude of sacrifice, and hard work.

Parents will always function in directing their children based on the Kalwedo cultural values themselves. In the past, every parent has the right to determine a mate for their children. But at the present time the determination of a mate by parents is less practiced. This happens because the determination of mate by parents is considered irrelevant in the present, where each child should be free to choose their own spouse. Engagement ties to the West Babar indigenous people, for example on Wetang Island, are usually characterized by the provision of certain items from the parents of men to the parents of women. Giving can be in the form of fiance rings, clothing, segeru, coconuts, fish, soap, and other items. These items are usually called wurakaiti. When translated freely, then wurakaiti can mean goods or items.

If during the engagement phase there is a misappropriation of the bride and groom, for example, marrying another man, then the male offender can be withdrawn from the female side, but in the form of a fine in the form of one pair of gold and one basta cloth. This shows the application of values of responsibility that are in line with the kalwedo culture.

\section{Specialization Phase}

The special phase (rlarawaka tutawula) is the second stage in the West Babar traditional wedding ritual. This phase is usually preceded by notification from the male side to the female family. The news anchor always uses kalwedo greetings when entering the candidate's house (girl). If the woman accepts it, they will respond with kalwedo words from inside the house. The notice was then conveyed, which essentially asked for the willingness of the female family. Next they discussed the right time to make a special trip. If it has been agreed upon by both parties, then the process of specialization can be carried out. The general process of specialization can be explained as follows: first, in accordance with the custom in force in customary marriage, the parents of men must convey their intentions to the makodiplola in this case saniri soa that they intend to make a special offer. Makodiplola, the male family, then conveyed the intention to the female family of makodiplola. Generally, the custom communication process is always built with kaldedo greetings to show a sacred heart sincerity. Furthermore, the makodiplola of the women's family gathered the family to determine the time for the special occasion. The agreement reached will be submitted to the male family through a contact called komruli.

Komruli is a liaison between the women's family and the male family. The communication process between komruli and family always begins with the kalwedo greeting. The main task of a komruli is to discuss and determine the time of the party with the male family as a place of interest for the female family.

Secondly, the requirements for specialization according to customary requirements are the preparation of one betel leaf and betel nut as much as one lildiamna (betel leaf place), one lildiamna tobacco, and one bottle of sopi water. Lildianmna is a place of betel leaves woven from pandan leaves in certain shapes and sizes. 
Third, in the implementation of the time-agreed specialization, the male family came to the women's family. After arriving at the house of the female family and welcome to enter, they first deliver the Kalwedo greetings and are returned by the female family with the words Kalwedo. Furthermore, the ingredients in the form of betel leaves, betel nut, tobacco, and sopi water carried by the male family were placed on the table. These materials cannot yet be utilized, especially for sopi water, which cannot be drunk, if the wishes of the male family have not been approved by the female family. Even so, because of customary demands, the women's family continues to serve the male family with the same material. This was done as a form of appreciation to the male family.

Fourth, there is only one spokesperson from each party. In general, the delivery of the intentions of both parties begins with the Kalwedo greeting and is greeted royally by the audience with the words hoe, then the purpose is symbolically expressed through traditional language. The customary language in question is a language specifically used in customary events and is not commonly used in everyday life. The male family can express their wishes as follows:

"kalwedooo ama yali ina nara amaidie makpeitiaramma winione itie laadipede mmaipie mawakepe mpiara mlakoye, kalwedo...".

The meaning: Greet peace, my new family, we see that there are superior seeds here. Therefore we came to ask him to keep it, kalwedo ... (Watloly, et al, 2012: 258).

When a female family welcomes the Kalwedo greeting, it means that the arrival of the male family is blessed and well received. Kalwedo is a typical greeting of indigenous people on the island of Wetang, which applies generally in daily association but can also be used in formal events. When a woman's family approves, then the sopi water, betel nut, betel leaf, and tobacco brought by the male family can be eaten and drunk together. Sopi water is a symbolic meaning of a male family. If the request to marry a male family is rejected, soopi water and other luggage must be brought back.

Fifth, after enjoying a meal brought by a male family, then the female family responds using traditional language, such as "oo Kalwedo ama yali ina nara, matrimantarnieka wakwamidinema, mawakde mmpiarpespese enekwali oriayami mmpiareme, nlaape natilna nawoo de myoratreri onni ede aai". Meaning: peace be upon you, we accept your request, but we ask that our child be guarded as we ourselves guard it and in time if he has been with you so that you never forget us.

The male and female families then discuss marriages including marriage assets (nwaneliwokwokni nialeini). In Wetang customary marriage, the property of marriage is only a symbol and more important is niolilieta (living well and loving each other). According to the Wetang people, marriage is not a buying and selling transaction like the expression "Nalekle uliuli de adi riorni ma liani de melima de tartore tarwelue so tnioorni wnieli neka nioli pespese rletpespesa hartani dede tomma. Nlape nioli nala mde raan kuona kai, riwre rano ranattie" (since ancient times according to customary regulations, marriage is not buying and selling, because the marriage property is living well. Happiness is a valuable asset as a provision to enter and live a marriage life. If in the future the husband's life behavior is not good, then a wife may advise him.

The next stage is naanawelatioa. The naanawelatioa program has three stages, the first stage (iine). In the first stage, the demands that must be fulfilled by male families in the customary provisions were two pigs and two goats. The second stage (but this), is done the next day. One goat was burned in this second stage (it must be burned and the horns must be wrapped so that it does not burn) and one pig was also burned the same day. Next is the preparation stage for teteta (chopping meat) and daini (chopping base). Traditionally, it was worth gold and basta cloth (in time it will be returned to the male family) and removed from the storehouse of male property (lokra or kotawnyota). Lokra means container 
and kowtanyota means the contents of the container. If a man comes from another customary environment, he must pay one pair of gold and one cloth basta as a sign of marriage and is called wurawadki (lamp). So the treasure is likened to a shining lamp in a female family's house and serves as a liaison for two families.

Third stage, riniorarapnyora (serving). Services from the male family to the female family to end the naanawelatioa and farewell program. Naanawelatioa has a positive value that is reminiscent of the husband's responsibility towards his wife. Naanawelatioa reminded husbands that the assets that are worthy of entering marriage are mutual respect, respect, and a good life (niolipespesarletpespesa).

\section{Marriage Phase}

The final stage in the Southwest Moluccas community wedding tradition is the conduct of marriage. In accordance with custom, the two brides must use the traditional clothes of koka, lelimaa, wui, krapmaa (basta cloth, gold bracelets, necklaces, gold earrings). Male traditional clothing, namely using basta cloth on the head shaped skullcap, basta cloth scarves, basta cloth as a belt (nalawra), and wearing gold in the ear. Women's traditional clothing, namely, using basta cloth (nalawra), black clothes (cele), moon gold on the forehead, crescent gold on the chest, and gold earrings on the ears.

Before the bridegroom is escorted to the bride's home, there is advice given by the family or parents. The counselor says kalwedo and is welcomed with hoe (truly and surely), and vice versa with the bride. Then the bridegroom is escorted to the bride's house accompanied by a traditional song. After arriving at the bride's house, the male elders knock on the door with a song called diarki (a type of traditional song sung at certain events, such as marriage ceremonies, construction of traditional houses, and family relationship building activities). Diarkii which is sung must be inspired by a cheerful, peaceful and joyful spirit. Diarkii which is imbued with the spirit of Kalwedo and the message to live a good life that describes life intimacy, brotherhood, manners, and mutual respect. If the chanting of diarchy is penitniarni and marani wurni (showing off wealth and greatness) then it will not be permitted to enter the house and the door will be closed. If the female family has said the door is not locked, it is an invitation for the male family to enter the house.

After entering, the male family shook hands with the female family. After that the groom sits next to the bride. Furthermore, customary marriages are carried out (rorni ma liani) by rieramama (custom leader). The customary leader endorses marriage with nlookra. Nlokra is a request for blessing and protection for the household of the two brides. Reyramarna is an important figure in the village. This figure is considered authoritative and masters the custom provisions, history, and special knowledge relating to various rites. Reyramarna plays an important role in intellectual rites. In accordance with the times, in addition to customary marriage, also carried out at the Civil Registry Office, confirmation and blessing were carried out ecclesiastically by the Pastor. The wedding program is generally accompanied by eating together and singing traditional songs that contain prayers so that the bride and groom are blessed. For example:

"O Riwao mlima meriayo, o Mriei wukiamunio rayamao, o Rayamai yominio kpoli wulio, Hi nararer moililio" (meaning: because of the marriage of the two brides of the family from various gathering places, gathered together and together to God to protect the bride and groom's household) (Watloly, 2012). The wedding program is accompanied by a traditional dance called seka (done by making a circle and holding hands). In the middle of the circle there is a big tifa with two legs or pray and is beaten by one or two people. Two or three people beat a small tifa. Small Tifa is a tifa that is not legged and is called tiwla, besides that one or two women are dancing or nloy. 


\section{Conclusion}

Kalwedo is a local culture of southwest Moluccas that is manifested in traditional marriage rituals. The noble values in kalwedo are integrated in the stages of the ritual. There are three phases of customary marriage rituals in western babar, namely the ratutri rania (engagement), rlarawaka tutawula (submission), and the core marriage phase. From these stages can be identified some of the noble values of kalwedo that exist in the ritual of traditional marriage, among others, mutual respect, cooperation, mutual cooperation, and social care. It is hoped that these values will be preserved to safeguard the ancestral cultural heritage and strengthen community social solidarity.

\section{References}

Aholiab Watloly, Fransina Matakena, Dominggus Saiya, dan Frans Dahaklory. (2012). Budaya Kalwedo di Moluccas Barat Daya. Ambon: Balai Pelestarian Nilai Budaya Ambon.

Geertz, Clifford. (1992). Tafsir Kebudayaan (diterjemahkan Fransisco Budi Hardiman). Yogyakarta: Kanisius.

Husmiwati , Kurnia dan Nova Yohana. (2015). Pemolaan Komunikasi Tradisi Basiacuang Sebagai Bentuk Kearifan Lokal Dalam Upacara Pernikahan Masyarakat Melayu Kampar Provinsi Riau (Studi Etnografi Komunikasi Tradisi Basiacuang di Desa Kuok Kecamatan Kouk Kabupaten Kampar). Riau: Jurnal Online Mahasiswa UNRI Vol.2 No.1 Februari 2015.

Leunupun, D. (2012). Berteologi dalam Konteks Budaya, Suatu Studi TentangNiolilieta di Pulau Wetang Kabupaten Moluccas Barat Daya. Ambon: Pratama Media.

Ngabalin, Marthinus. (2008). Perkawinan Custom: Tinjauan Pastoral Keluarga di Kepulauan Kei. Jurnal Ilmiah STAKP Negeri Ambon.

Strauss, Anselm dan Juliet Corbin. (2009). Dasar-dasar Penelitian Kualitatif. Yogyakarta: Pustaka Belajar Van Peursan, C.A. 1988. Strategi Kebudayaan. Diterjemahkan Oleh Dick Hartoko. Yogyakarta:

KanisiusVerkuyl, J.1979. Etika Kristen. Jakarta:BPK Gunung Mulia.

\section{Copyrights}

Copyright for this article is retained by the author(s), with first publication rights granted to the journal.

This is an open-access article distributed under the terms and conditions of the Creative Commons Attribution license (http://creativecommons.org/licenses/by/4.0/). 